\title{
風波乱流場での物質移動に及ぼす飛散液滴の影響*
}

\author{
杉岡健一*1, 小森悟*1

\section{The Effects of Droplets on Mass Transfer in Wind-Driven Turbulence with Breaking Waves}

\author{
Ken-ichi SUGIOKA and Satoru KOMORI ${ }^{* 2}$ \\ ${ }^{* 2}$ Department of Mechanical Engineering and Advanced Institute \\ of Fluid Science and Engineering, Kyoto University, \\ Yoshidahonmachi, Sakyo-ku, Kyoto-shi, Kyoto, 606-8501 Japan
}

\begin{abstract}
The effects of dispersed droplets on mass transfer across the air-water interface with breaking waves were experimentally and numerically investigated. The diameter, velocity and horizontal flux of droplets were measured using a phase Doppler anemometer. The results show that the horizontal flux of droplets has an unversal size distribution independent of wind speed and height, and that the horizontal flux of droplets increases in proportion to the 8th power of friction velocity. In addition, the mass transfer across the air-water interface of a single droplet was estimated by means of a direct numerical simulation (DNS). The DNS shows that the contribution of dispersed droplets to the total mass transfer across air-water interface with breaking wave is about $0.3 \%$.
\end{abstract}

Key Words : Mass Transfer, Sea Spray, Breaking Wave, Air-water Interface

\section{1. 緒言}

近年話題となっている地球温暖化の主な原因として, 化石然料の大量消費に伴う大気中の二酸化炭素 $\left(\mathrm{CO}_{2}\right)$ 濃度の上昇が挙げられる. 地球温暖化を正確に予測す るためには地球規模での $\mathrm{CO}_{2}$ の循環機構を解明し, 高 精度の予測モデルを開発することがきわめて重要であ る. しかし, 地球規模での $\mathrm{CO}_{2}$ の循環システムが非常 に複雑であり, その正確なモデル化が行われていない ため, 地球規模での $\mathrm{CO}_{2}$ 循環量の予測において, $\mathrm{CO}_{2}$ の放出量と吸収量の収支が大気中に蓄積する $\mathrm{CO}_{2}$ 量 と合わないという問題が生じている. その原因の一つ として, 地球の表面積の約 7 割を占める海洋と大気間 での $\mathrm{CO}_{2}$ の交換量が正確に評価されていないことが 挙げられる.

大気・海洋間, すなわち風波気液界面を通しての物 質移動速度を評価する試みの中で, 風速が大きくなり 風波界面が崩壊する砕波域と呼ばれる領域での物質移 動速度が，砕波していない状態と比較して急激に上昇 する傾向があることが明らかにされている(1)(2). 砕波 域で物質移動速度が急増する要因として, 砕波によっ て生じる気泡の巻き込みや液滴の飛散現象などが挙げ

\footnotetext{
* 原稿受付 2004 年 2 月 20 日.

*1 正員, 京都大学大学院工学研究科( 606-8501 京都市左京 区吉田本町)

E-mail : komori@mech.kyoto-u.ac.jp
}

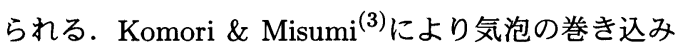
は風波気液界面全体における物質移動に対する寄与が 最大でも $7 \%$ 程度しかないことが明らかにされている. しかし, 研波によって生じる飛散液滴が風波気液界面 全体における物質移動に対してどれほど寄与するのか は, 従来の研究でも明らかにされていない. そこで, 本研究では确波域における飛散液滴が物質移動に及ほ す影響を明らかにすることを目的とする.

物質移動に関して飛散する液滴の寄与を明らかにす るためには, 単一液滴に対する物質移動量と風波乱流 場を飛散する液滴の数密度が必要となる．また，単一 液滴に対する物質移動量は液滴の挙動に関係すると予 想される.これらの情報を得るためには, 砕波によっ て生じる液滴の径, 速度, 気流との相対速度, 数密度 等を計測することが必要となる. しかし，これまでの 海洋観測 ${ }^{(4) \sim(7)}$ や風波乱流水槽を用いた研究 ${ }^{(8) \sim(11)}$ は正確な測定が行われておらず，飛散液滴に関する諸 特性は大きくばらついており, 完全には把握されてい ない. また, 数密度は飛散量と夜滴の速度により算出 できるが, Toba ${ }^{(8)}$ や Lai \& Shemdin ${ }^{(9)}$ は気流の流速 を液滴の速度とし, Koga \& Toba ${ }^{(11)}$ は液滴の速度を 簡単なモデルで与えており, 飛散液滴の速度を実際に 測定して与えてはいない. そこで, 本研究では砕波に より生じる飛散液滴の諸量を定量的に評価するため, 
海洋のシミュレーション装置である風波乱流水槽を用 いた室内実験を行った．また，単一液滴に対する物質 移動量を明らかにするために直接数值計算法 (DNS) による数值計算を行った．それらの知見を用いて，風 波乱流場の物質移動に及ぼす飛散液滴の影響を明らか にした.

\section{2.おもな記号}

$A \quad$ : 液滴の表面積

$C$ ： 物質濃度

$C_{D}:$ 抗力係数

$d \quad:$ 液滴の直径

$D_{L} \quad$ ： 物質の分子拡散係数

$F \quad: \quad$ 液滴の飛散量

$f \quad$ : 飛散液滴の径に対する確率密度

$H_{s} \quad$ ： 有義波高

$k_{L} \quad$ ： 物質移動係数

$N$ ： 液滴の総数

$p$ : 圧力

$Q$ : 物質移動量

$R e_{p} \quad$ : 粒子レイノルズ数 $\left(=\frac{U_{c} d}{\nu_{f}}\right)$

$S c \quad$ : シュミット数 $\left(=\frac{\nu}{D_{L}}\right)$

$S h \quad$ : シャーウッド数 $\left(=\frac{k_{L} d}{D_{L}}\right)$

$U$ ：主流方向速度

$U_{c} \quad$ ：流体と液滴の相対速度

$U_{\infty} ：$ 気流の一様流速

$u^{*}$ : 摩擦速度

$z \quad: \quad$ 静水面からの鈶直方向距離

$\kappa$ : Karman 定数

$\nu$ : 動粘性係数

$\rho \quad:$ 密度

$\mu \quad$ : 粘性係数

$\tau$ : せ九断応力

\section{3. 崩壊する風波気液界面上の液滴の飛散機構}

3.1 実験装置および実験方法図 1 に実験に用 いた風波乱流水槽および測定システムの概略図を示 す. 風波乱流水槽の全長は $10 \mathrm{~m}$ であり, ガラス製の テストセクション部分は全長 $6.5 \mathrm{~m}$, 全幅 $0.3 \mathrm{~m}$, 全 高 $0.8 \mathrm{~m}$ で, 槽底における壁乱流が気液界面に及ぼ す影響を防ぐために液深を $0.5 \mathrm{~m}$ と十分深くした. 風 洞ファンから排出される空気を 3 枚の整流スクリー ンおよびハ二カムで整流した後, 水槽内の気液界面上 の $0.3 \mathrm{~m} \times 0.3 \mathrm{~m}$ の正方形ダクト内に流し, 風波を 発生させた. 一様流速 $U_{\infty}=14 \mathrm{~m} / \mathrm{s}$ 以上の高風速域に おいて風波が激しく崩壊し, 液流側への気泡の巻き込

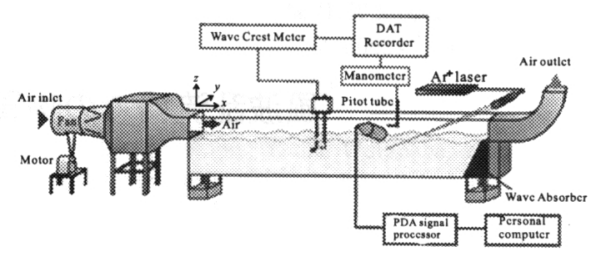

Fig. 1 Schematic diagram of the experimental apparatus.

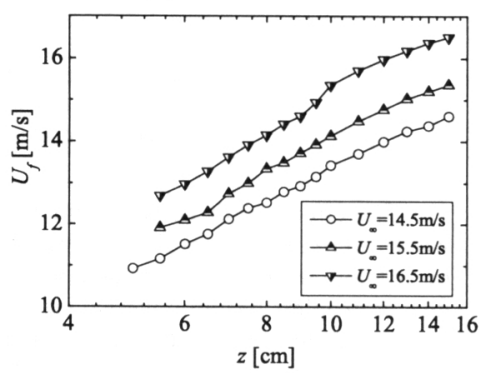

Fig. 2 Vertical distributions of the mean wind speed.

Table 1 Experimental conditons.

\begin{tabular}{c||c|c}
\hline $\begin{array}{c}U_{\infty} \\
(\mathrm{m} / \mathrm{s})\end{array}$ & $\begin{array}{c}u^{*} \\
(\mathrm{~m} / \mathrm{s})\end{array}$ & $\begin{array}{c}H_{s} \\
(\mathrm{~cm})\end{array}$ \\
\hline 14.5 & 1.33 & 5.20 \\
15.5 & 1.46 & 5.42 \\
16.5 & 1.60 & 5.45 \\
\hline
\end{tabular}

み, 気流側への液滴の飛散が観察された. 本研究では, この高風速域において実験を行った．風波乱流水槽内 の気流の時間平均流速をピトー管と沈鐘式精密微差 圧計 (柴田科学 (株) ISP-350) を用いて, 気側に飛散 する液滴の径 $d$, 速度 $U_{d}$, 飛散量 $F$ を 2 カラー $\mathrm{Ar}^{+}$ レーザ (LEXEL model95-2 : 波長 448.0nm, 514.5nm; 出力 $0.3 \mathrm{~W})$ を光源とした位相ドップラ方式粒子計測 計 (PDA:DANTEC 58N80-SYSTEM) を用いて測定 した. 本実験では測定位置を吹送距離 $x$ が水槽部の入 口 $(x=0 \mathrm{~m})$ から $5 \mathrm{~m}$, 静水面からの鈶直方向距離 $z=0.06 \sim 0.15 \mathrm{~m}$ の位置とした

実験条件として砕波が起こり, 液滴の飛散現象が見 られる気流の一様流速 $U_{\infty}=14.5,15.5,16.5 \mathrm{~m} / \mathrm{s}$ の 3 風 速の場合に対して実験を行った. 各一様流速 $U_{\infty}$ に対 する時間平均流速 $U_{f}$ の鈶直方向分布を図 2 に各一様 流速 $U_{\infty}$ に対する摩摖速度 $u^{*}$ および有義波高 $H_{s}$ を 表 1 に示す.

3.2 結果および考察 図 3 に $U_{\infty}=14.5 \mathrm{~m} / \mathrm{s}$ で の液滴の速度 $U_{d}$ と液滴径 $d$ の関係を示す. 縦軸は各 


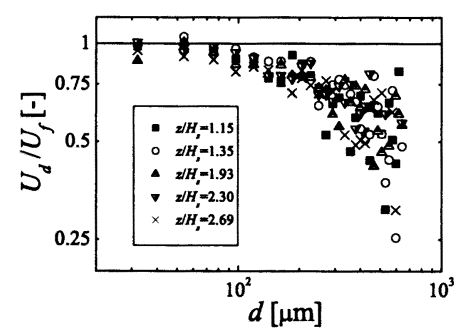

Fig. 3 Size distributions of the droplet velocity normalized by wind velocity, $U_{d} / U_{f}$, at $U_{\infty}=14.5 \mathrm{~m} / \mathrm{s}$.

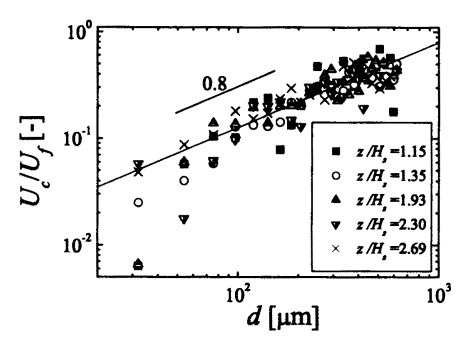

Fig. 4 Size distributions of the relative velocity between wind and droplet normalized by wind velocity, $U_{c} / U_{f}$, at $U_{\infty}=14.5 \mathrm{~m} / \mathrm{s}$.

測定点での時間平均流速 $U_{f}$ で無次元化した. 図 3 か ら, $U_{d} / U_{f}$ は液滴径 $d$ が大きくなると減少すること, 測定値はばらついているものの測定点によらずほぼ同 一の関数形で与えられることがわかる. 図 4 に液滴と 気流の相対速度 $U_{c}$ と液滴径 $d$ の関係を示す. 縦軸は 相対速度を図 3 之同様に各測定点での風速 $U_{f}$ で無次 元化したものを示す. 図 4 から， $U_{c} / U_{f}$ もばらつきは 大きいが測定点によらずに同一の関数形で表されるこ とがわかる. また, $U_{c} / U_{f}$ はほぼ $d^{0.8}$ に従い增加す ることがわかる. 図を省略するが, この結果は風速を 変化させても同様であった. これらの結果から, 相対 速度に基づく液滴の粒子レイノルズ数 $R e_{p}$ は $U_{f}$ とd, 空気の動粘性係数 $\nu_{f}$ を用いて実験的に

$$
R e_{p}=200 \times U_{f} d^{1.8} / \nu_{f}
$$

で与えられる.

図 5(a) に有義波高で無次元化された鈶直方向距離 $z / H_{s}=1.35$ において風速を変化させた場合での, 図 $5(\mathrm{~b})$ に $U_{\infty}=14.5 \mathrm{~m} / \mathrm{s}$ で位置を変化させた場合での飛 散液滴の径の分布 $f(d)$ を示す.これらの図から, $f(d)$ は風速, 鈶直方向位置を変化させても, 近似的に同一

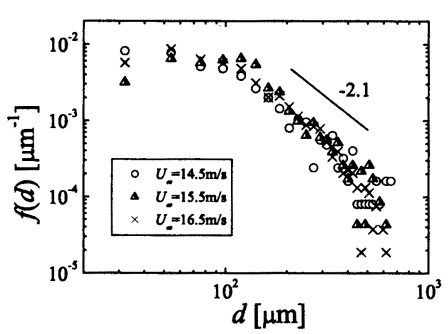

(a)

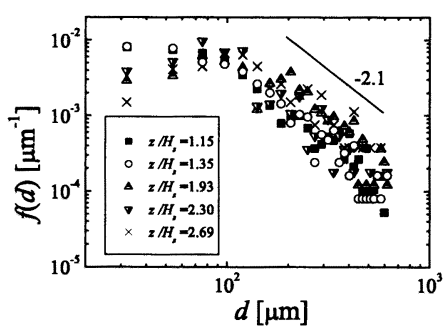

(b)

Fig. 5 Size distributions of droplets: (a) at $z / H_{s}=1.35$; (b) at $U_{\infty}=14.5 \mathrm{~m} / \mathrm{s}$.

の関数形で与えられることがわかる. また, $f(d)$ は $d<100 \mu \mathrm{m}$ では一定値を取り, $d \geq 100 \mu \mathrm{m}$ では $d^{-2.1}$ に従い隇少することがわかる. 従って, 飛散液滴の径 の分布 $f(d)$ は $U_{\infty}, z / H_{s}$ によらず， $d$ を用いて実験 的に

$$
\begin{aligned}
& f(d)=5.6 \times 10^{-3} \quad d<100 \mu \mathrm{m} \\
& f(d)=88 \times d^{-2.1} \quad 100 \leq d \leq 650 \mu \mathrm{m} . .
\end{aligned}
$$

で与えられる.

図 6 に液滴の飛散量 $F$ と摩擦速度 $u^{*}$ の関係を示す. 図 6 から, 測定点 $z / H_{s}$ が変化することにより $F$ は変 化するが, $F$ は $u^{* 8}$ に従い增加するという関係が測定点 によらず存在することがわかる. 図 7 に飛散量 $F$ の鈶 直方向分布を示す. 縦軸は波頂付近の飛散量 $F_{0}$ で割つ て無次元化されている. 図 7 から, $F / F_{0}$ は $z / H_{s}<$ 1.5 では 1.0 であり, $z / H_{s} \geq 1.5$ では $\left(z / H_{s}\right)^{-2.7}$ に 従い減少することがわかる. $F / F_{0}$ は $z / H_{s}$ を用いて 実験的に

$$
\begin{array}{llrl}
\frac{F}{F_{0}} & =1.0 & \frac{z}{H_{s}} & <1.5 \\
\frac{F}{F_{0}} & =3.3 \times\left(\frac{z}{H_{s}}\right)^{-2.7} & \frac{z}{H_{s}} & \geq 1.5
\end{array}
$$

で与えられる．また， $F_{0}$ は図 6 から実験的に

$$
F_{0}=1.3 \times 10^{4} \times u^{* 8}
$$




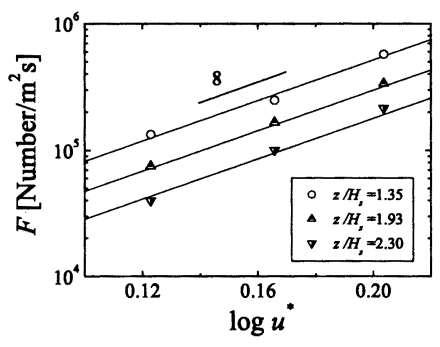

Fig. 6 Relation between $F$ and $u^{*}$.

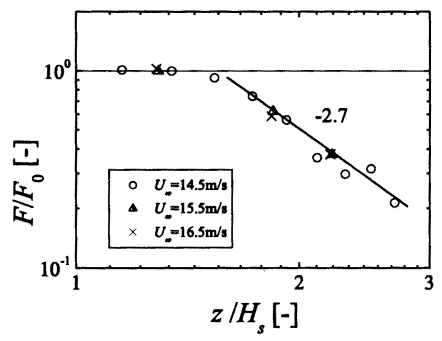

Fig. 7 Vertical distributions of $F / F_{0}$.

で与えられる. 従って, 液滴の飛散量 $F$ に対しては

$$
\begin{array}{ll}
F=1.3 \times 10^{4} \times u^{* 8} & \frac{z}{H_{s}}<1.5 \\
F=4.29 \times 10^{4} \times u^{* 8}\left(\frac{z}{H_{s}}\right)^{-2.7} & \frac{z}{H_{s}} \geq 1.5(5)
\end{array}
$$

の実験相関式が得られる.

\section{4. 単一液滴に対する物質移動係数の評価}

4.1 直接数値計算 (DNS) 図 8 に計算対象と した液滴周りと液滴内の座標系を示す. 座標系には円 柱座標形 $(x, r, \theta)$ を用いた。

支配方程式である連続の式

$$
\nabla \boldsymbol{V}=0
$$

と Navier-Stokes 方程式

$$
\begin{aligned}
& \frac{\partial U}{\partial t}+(\boldsymbol{V} \cdot \nabla) U=-\frac{\partial p}{\partial x}+\frac{1}{R e_{p, k}} \nabla^{2} U \\
& \frac{\partial V}{\partial t}+(\boldsymbol{V} \cdot \nabla) V-\frac{V^{2}}{r} \\
& \quad=-\frac{\partial p}{\partial r}+\frac{1}{R e_{p, k}}\left(\nabla^{2} V-\frac{V}{r^{2}}-\frac{2}{r^{2}} \frac{\partial W}{\partial \theta}\right) . \\
& \frac{\partial W}{\partial t}+(\boldsymbol{V} \cdot \nabla) W+\frac{V W}{r} \\
& =-\frac{1}{r} \frac{\partial p}{\partial \theta}+\frac{1}{R e_{p, k}}\left(\nabla^{2} W-\frac{W}{r^{2}}+\frac{2}{r^{2}} \frac{\partial V}{\partial \theta}\right)
\end{aligned}
$$

を解く方法として有限差分法に基づく MAC(Marker and Cell) 法(12) (13) を用いた. NS 方程式中の粒子レ

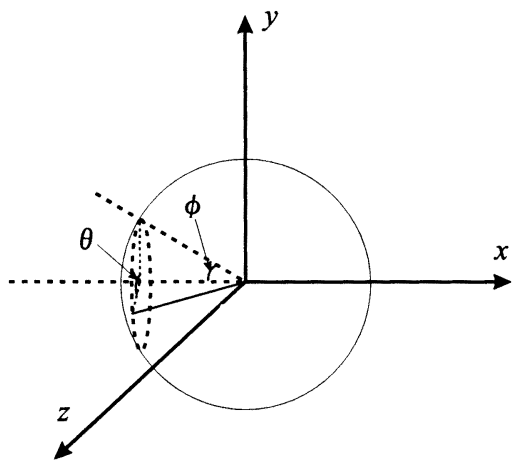

Fig. 8 Coordinate system for a spherical droplet.

イノルズ数 $R e_{p}$ の添え字 $k$ は液滴周り ( $k=\mathrm{o}$ ooutside) と液滴内 $(k=\mathrm{i}$ inside) を表す. 本数値計算では, 表面 張力の作用により液滴は変形せず, 常に球形をとると 仮定をした．また，DNS で得られた速度分布を用い て物質の輸送方程式

$$
\frac{\partial C}{\partial t}+(\boldsymbol{V} \cdot \nabla) C=\frac{1}{R e_{p, i} \cdot S c} \nabla^{2} C
$$

を解くことで濃度場の解析をも行った. このとき, 気 側のシュミット数 $S c$ は液側に比べて小さいため, 気 側を完全混合状態であると仮定し, 液滴内の液側のみ を解くことにより濃度分布を解析した. 一連の支配方 程式は代表長さ $d$, 代表速度 $U_{c}$, 代表濃度 $C_{0}$ を用い て無次元化した. 用いた流体の物性値を表 2 に示す. 表中の $\rho, \mu$ は流体の密度, 粘性係数で添え字は $R e_{p}$ と 同様である.このとき, 液滴周りと液滴内の粒子レイ ノルズ数は

$$
R e_{p, i}=\frac{\rho_{i}}{\rho_{o}} \frac{\mu_{o}}{\mu_{i}} R e_{p, o}
$$

の関係にある. 支配方程式の離散化については, 液滴 周りの対流項には 3 次精度の風上差分スキーム ${ }^{(14)}$ を, その他の空間微分項には 2 次精度の中心差分を適用 した.

液滴周りおよび夜滴内の格子点の概略図は図 9 に 示す通りであり, 計算格子点数は液滴周りについては $35 \times 61 \times 48$, 液滴内に対しては計算条件が $R e_{p}<100$ の場合は $35 \times 31 \times 48, R e_{p} \geq 100$ の場合は $35 \times 61 \times 48$ であった.

周囲流を一様流とし, 液滴の中心は円柱座標系では 特異点となるため,

$$
U(x, 0, \theta)=\frac{U(x, \Delta r, \theta)+U(x, \Delta r, \theta+\pi)}{2}
$$

により補完して与えた. 液滴表面の境界条件は, 法線 方向を $n$, 接線方向を $\theta$ および $\phi$ として，1) 流体は界 面を横切らず, 液滴は変形しない, 2) 液滴表面での接 線方向のせん断応力は連続性を保つ, 3) 液滴表面での 


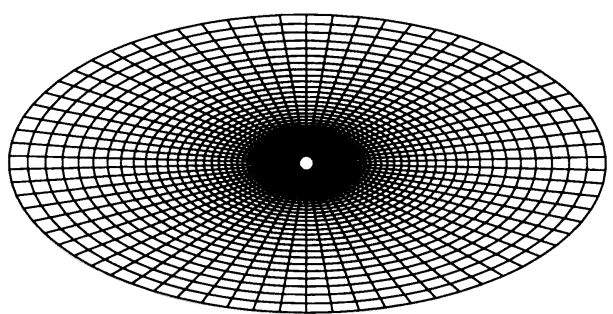

(a)

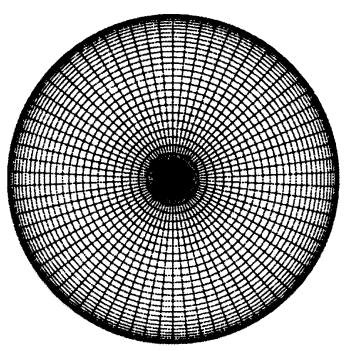

(b)

Fig. 9 Schematic diagram of the computational domain (a) outside and (b) inside a spherical droplet.

速度は連続性を保つの条件下で

$$
\begin{aligned}
v_{n, o} & =v_{n, i}=0 \\
\tau_{n \theta, o} & =\tau_{n \theta, i} \ldots \\
\tau_{n \phi, o} & =\tau_{n \phi, i} \ldots \\
v_{\theta, o} & =v_{\theta, i} \ldots \\
v_{\phi, o} & =v_{\phi, i} \ldots
\end{aligned}
$$

を満たすようにした， $v, \tau$ の添え字 $\mathrm{o}, \mathrm{i}$ は液滴周り および液滴内の速度, せん断応力を表す. 濃度の境界 条件として, 界面での物質濃度 $C_{s}$ を

$$
C_{s}=1.0 \ldots
$$

とした. また, 液滴内の初期濃度を 0 と設定した.

液滴に衝く流体力 $\boldsymbol{F}$ を

$$
\boldsymbol{F}=\int_{S}-p \boldsymbol{e}_{n}+\tau d S
$$

から求めた.ここで， $e_{n}$ は界面に対して法線方向の 単位ベクトル， $\tau$ は液滴表面に作用するせん断応力で ある. 液滴に働く流体力 $\boldsymbol{F}$ を

$$
\boldsymbol{C}=\frac{\boldsymbol{F}}{\frac{1}{2} \rho_{o} U_{c}^{2} \pi\left(\frac{d}{2}\right)^{2}}
$$

で無次元化した主流方向 ( $x$ 方向) 成分が抗力係数 $C_{D}$ である。

無次元化された液滴の気液界面を通しての物質フ ラックス $F_{m}$ および物質移動係数 $k_{L}$ の無次元数であ るシャーウッド数 $S h$ は気液界面での法線方向の物質
Table 2 Fluid properties.

\begin{tabular}{c|c}
\hline$S c_{i}$ & 600 \\
\hline$\mu_{o}$ & $18.20 \times 10^{-6} \mathrm{~kg} / \mathrm{m} \mathrm{s}$ \\
\hline$\mu_{i}$ & $890.9 \times 10^{-6} \mathrm{~kg} / \mathrm{m} \mathrm{s}$ \\
\hline$\rho_{o}$ & $1.185 \mathrm{~kg} / \mathrm{m}^{3}$ \\
\hline$\rho_{i}$ & $997.0 \mathrm{~kg} / \mathrm{m}^{3}$ \\
\hline
\end{tabular}

濃度こう配 $\frac{\partial C}{\partial n}$ を用いて

$$
F_{m}=S h\left(C_{s}-C_{L}\right)=\frac{1}{A} \int_{S} \frac{\partial C}{\partial n} d S
$$

と表される. $C_{L}$ は液滴内の平均濃度である. 液相 $(S c=600)$ での物質拡散は一般に DNS の適用は困 難といわれている. しかし, 計算格子数を段階的に変 化させて計算を行い, 本 DNS で用いた計算格子数で 液滴表面近傍での濃度こう配を評価できることを確認 した.

DNS を実行する際のパラメー夕は液滴周りで の粒子レイノルズ数 $R e_{p}$ であり, $R e_{p}=1 \sim$ $300(1,5,10,50,100,300)$ の範囲で計算を実行した. 無 次元化した計算ステップは 0.005 とし, 流動場が充分 発達した後に流動場と濃度場の解析を 60000 ステップ に対して行った.

4.2 結果と考察 図10(a)に液滴周りの，(b)に 液滴内の $R e_{p}=50$ における $x-y$ 断面の流速ベクトル 分布と流湶を示す. 図10(a) から, 流れは主流方向で ある $x$ 軸に対して軸対称な流動場を形成し, 液滴の 後部において流れの剥離が生じることがわかる. 図 10 (b) から液滴内部には循環が存在することがわかる. $R e_{p}=300$ においては液滴周りに図 11 に見られるよ うな非定常渦が見られた．流動場が DNSにより忠実 に再現されているかどうかを確認するため, 液滴に働 く抗力係数 $C_{D}$ を評価した. 図 12 に粒子レイノル ズ数 $R e_{p}$ に対する液滴に働く抗力係数 $C_{D}$ の変化を 示す. 図中の実線は Beard \& Pruppacher ${ }^{(15)}$, 破線は Gunn \& Kinzer ${ }^{(16)}$ によって提案された実験相関式で ある. 図 12 から本数値計算の結果は実験相関式と良 好に一致をしていることがわかる.このことから, 本 数値計算は一様流中の液滴の流動場を忠実に再現して いることがわかる.

図 13(a)(b)(c)に $R e_{p}=50$ における，無次元時間 $t^{*}=50,100,200$ に対する液滴内の $x-y$ 断面での濃度分 布を示す. $t^{*}=0$ は濃度場の解析をはじめた瞬間であ る. 図 13(a) から, 時間の経過とともに液滴界面付近 の物質は循環流により下流側に運ばれることがわかる. その後, 図 13(b)(c) に見られるように下流側に運ばれ た物質はやがて液滴中心部に輸送され, 再び界面付近 に輸送されることがわかる. 次に, 得られた濃度分布 


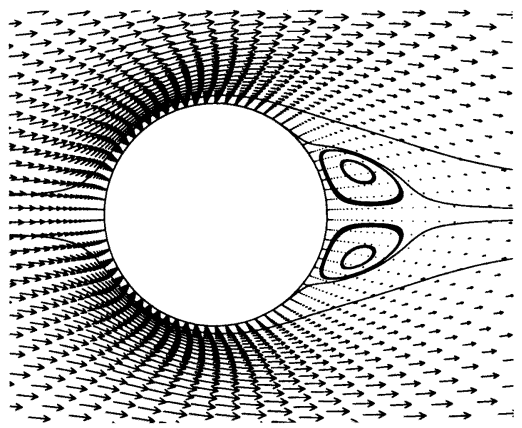

(a)

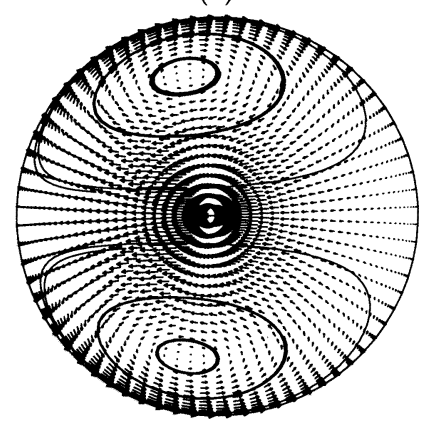

(b)

Fig. 10 Schematic diagram of the velocity fields and stream lines at $R e_{p}=50$ : (a) outside ;(b) inside a spherical droplet.

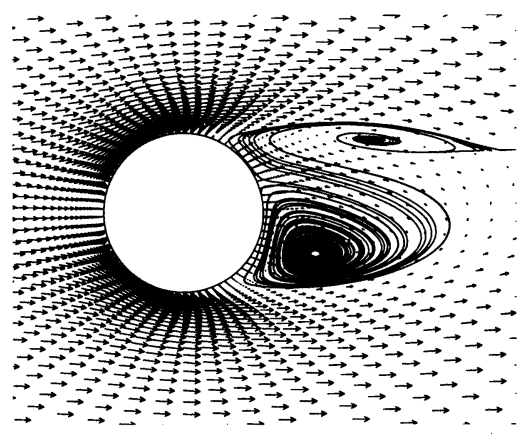

Fig. 11 Schematic diagram of the velocity fields and stream lines outside a spherical droplet at $R e_{p}=300$.

から気液界面を通しての物質フラックスを $(21)$ 式を用 いて評価した. 図 14 に無次元の物質フラックス $F_{m}$ の 時間変化を示す. 横軸は無次元時間 $t^{*}$ である. 図から $F_{m}$ は時間の経過に従い減少する傾向があることがわか る. また, 四から $t^{*}<10$ において $F_{m}$ は $t^{* 1 / 2}$ に従い

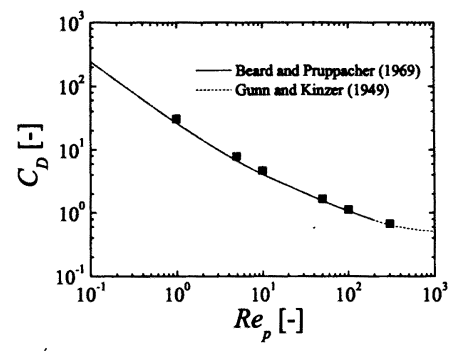

Fig. 12 Drag coefficient $C_{D}$ versus the particle Reynolds number $R e_{p}$.

滅少することがわかる. さらに, $F_{m}$ は $10<t^{*}<100$ においては一定値に漸近し, $100<t^{*}<300$ において $F_{m}$ が再び大きく減少することがわかる．このことは, 図 13(a)(b)(c) に見られるように, $t^{*}>100$ では循環 流により高濃度の流体塊が界面付近に輸送されるため に界面付近の濃度こう配が緩やかになるからである. ただし， $R e_{p}=300$ では $150<t^{*}<300$ において非 定常渦の影響により生じる流れによって, 他の条件と 異なる流動場となるために物質フラックスも異なる挙 動を示すが，時間が経過するに従い，ほぼ一定值とな る. 図 15 に $t^{*}=1,10,100,200,300$ でのシャーウッド数 $S h$ と粒子レイノルズ数 $R e_{p}$ の関係を示す. 図 15 か ら $t^{*}=1,10$ においては $S h$ は $R e_{p}^{0.5}$ に従うが時間が経 過するに従い, $S h$ と $R_{p}$ の関係が不規則に変化する ことがわかる.

\section{5. 風波乱流場での物質移動に及ほす飛散液滴の影䇺}

風波乱流水槽を用いた実験により得られた砕波域に おける飛散液滴の諸量および単一液滴に関する直接数 値計算により得られた単一液滴に対する物質移動係数 を用いて, 風波乱流場の飛散液滴全体による物質移動 量を物質移動係数 $k_{L t}$ として以下の手順により評価を 行った.

挽波により発生する液滴全体の単位時間あたりの物 質移動量 $Q_{t}$ は, 単一液滴からの単位時間あたりの物 質移動量の総和として,

$$
Q_{t}=\sum_{j}^{N} k_{L, j} A_{j}\left(C_{s}-C_{L, j}\right)
$$

で表される.ここで， $N$ は物質移動に寄与する液滴の 総数, $k_{L, j}$ は $j$ 番目の単一夜滴に対する物質移動係数, $A_{j}$ は $j$ 番目の単一液滴の表面積, $C_{s}$ は気液界面での 物質濃度, $C_{L, j}$ は液滴の平均物質濃度である. 単一液 滴に対する物質移動係数 $k_{L, j}$ は図 15 のシャーウッド 


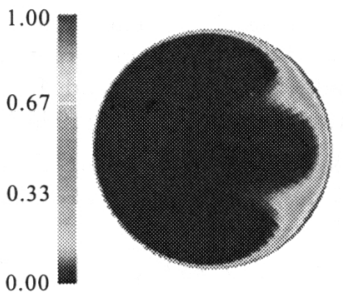

(a)

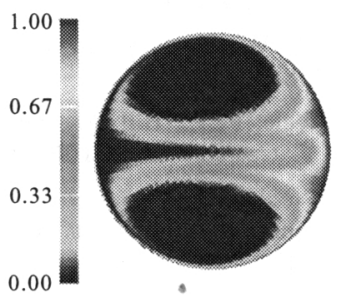

(b)

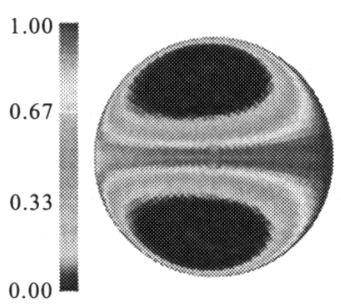

(c)

Fig. 13 Profiles of the instantaneous concentration inside a spherical droplet in the $x-y$ plane at $R e_{p}=50$ (a) $t^{*}=50$ (b) $t^{*}=100$ (c) $t^{*}=200$.

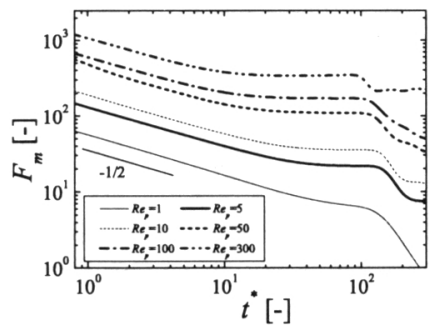

Fig. 14 Dimensionless mass flux across the interface $F_{m}$ versus dimensionless time $t^{*}$.

数 $S h$ を用いて算出する．ここで飛散夜滴による単位 時間あたりの物質移動量の最大の影響を評価するため に, シャーウッド数 $S h$ の值は直接数值計算により得

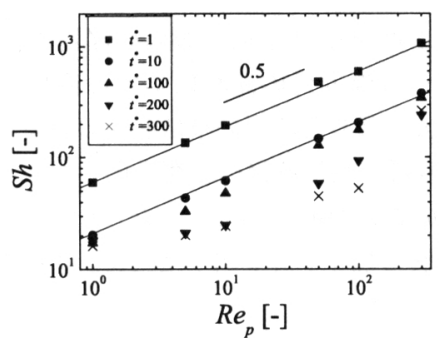

Fig. 15 The Sherwood number $S h$ versus the particle Reynolds number $R e_{p}$.

Table 3 Comparisons of mass transfer coefficient.

\begin{tabular}{c||c|c|c}
\hline$U_{\infty}[\mathrm{m} / \mathrm{s}]$ & $k_{L t}[\mathrm{~m} / \mathrm{s}]$ & $k_{L S}[\mathrm{~m} / \mathrm{s}]$ & $k_{L t} / k_{L S}$ \\
\hline \hline 14.5 & $1.65 \times 10^{-7}$ & $1.91 \times 10^{-4}$ & $8.65 \times 10^{-4}$ \\
\hline 15.5 & $3.39 \times 10^{-7}$ & $2.28 \times 10^{-4}$ & $1.49 \times 10^{-3}$ \\
\hline 16.5 & $6.81 \times 10^{-7}$ & $2.71 \times 10^{-4}$ & $2.51 \times 10^{-3}$ \\
\hline
\end{tabular}

られた無次元時間 $t^{*}=1$ での相関式 (図 15$)$

$$
S h=60 \times R e_{p}^{0.5}
$$

を用いた。この $t^{*}=1$ は液滴が飛散を開始した直後 の瞬間に相当し, 飛散時間に比べて非常に小さい. 液 滴の総数 $N$ を式 $(2),(5)$ および夜滴の速度 $U_{d}$ を用い て, 高さ方向に積分することにより次式より求めた.

$$
N=A_{s} \iint \frac{F \cdot f(d)}{U_{d}} \mathrm{~d} d \mathrm{~d} z
$$

ここで, $A_{s}$ は液滴が飛散する風波気液界面の面積で ある. また, 液滴内の濃度は全て風波水槽内の夜側バ ルク濃度 $C_{B}$ として, 得られた飛散液滴による単位時 間あたりの物質移動量 $Q_{t}$ を算出し, 液滴全体に対す る物質移動係数 $k_{L t}$ を

$$
Q_{t}=k_{L t} A_{s}\left(C_{s}-C_{B}\right)
$$

により評価した.

この手法により，算出した $k_{L t}$ を Komori \& Shimada $^{(1)}$ が風波乱流水槽を用いた放散実験により 評価した風波気液界面全体に対する物質移動係数 $k_{L S}$ の実測值と比較した. その結果を表 3 に示す. 表から 界面が激しく崩壊する $U_{\infty}=16.5 \mathrm{~m} / \mathrm{s}$ においても, 飛 散液滴の物質移動に対する寄与は風波気液界面全体の 物質移動量に対して最大でも $0.3 \%$ 程度に過ぎないこ とがわかる，そのことから，砕波によって生じる液滴 の飛散現象が高風速域において飛躍的に物質移動が促 進される原因とはならないことが明らかとなった。 


\section{6. 結 言}

風波乱流水槽を用いた飛散液滴の諸特性の計測実 験および単一液滴内外の流れに対する直接数值計算 (DNS)により, 風波乱流場の飛散液滴の諸特性および 物質移動に及ぼす飛散液滴の影響を明らかした. その 結果, 以下のことが明らかになった.

1. 飛散液滴の粒子レイノルズ数 $R e_{p}$ は風速と液滴 径で相関される.

2. 液滴の飛散量は気流流速, 摩擦速度, 鈶直方向距 離で表される.また, 存在する液滴は $100 \mu \mathrm{m}$ ま で一定量で, 径が大きくなるに従い減少する.

3. 風波乱流場での全体の物質移動量に及ぼす飛散 液滴の影響は最大でも $0.3 \%$ 程度であり, 無視で きる.

\section{謝 辞}

本研究は文部科学省科学研究費補助金 (課題番号 14102016)の援助を受けて行われた. 本研究の一部は, 21 世紀 COE プログラム「動的機能機戌システムの 数理モデルと設計論」によるものである. また, 本 DNS は国立環境研究所地球環境センターのスーパコ ンピュータSX-6 を用いて行われた.

\section{文献}

(1) Komori, S. \& Shimada, T., Air-Water Gas Transfer (edited by B. Jahne and E. Monahan)., AEON Verlag ,553-569 (1995).
(2) Komori, S., Shimada, T. \& Misumi, R., Wind over wave couplings: Perspectives and prospects (Edited by S.G. Sajjadi, N.H. Thomas and J.C.R. Hunt), Clarendon Press Oxford, 273-285 (1999).

(3) Komori, S. \& Misumi, R., In AGU Geophysical Monograph Series, Gas Transfer at Water Surface, 285-290 (2001).

(4) Monahan, E. C., J. Geophys. Res.,73, 1127-1137 (1968).

(5) de Leeuw, G., Tellus, 38, 51-61 (1986).

(6) Blanchard, D. C., Woodcock A. H. \& Cipriano R. J., Tellus, 36, 118-125 (1984).

(7) de Leeuw,G., Neele, F. P., Hill, M., Smith, M. H. \& Vignati, E., J. Geophys. Res., 105, 29397-29409 (2000).

(8) Toba, Y., Memoirs. Coll. Sci., Univ. Kyoto, Ser. A, 29, 313-344 (1961).

(9) Lai, R. J. \& Shemdin O. H., J. Geophys. Res., 79, 3053-3063 (1974).

(10) Wang, C. S. \& Street, R. L., J. Geophys. Res., 83, 2959-2969 (1978).

(11) Koga, M. \& Toba, Y., Rep. Tohoku Uviv.,Ser. 5. 28, 1-25 (1981).

(12) Hanazaki H., J. Fluid Mech., 192, 393-419 (1988).

(13) Kurose R. \& Komori S., J. Fluid Mech., 384, 183206 (1999).

(14) Kawamura, T. \& Kuwahara, K., AIAA paper, 840340 (1984).

(15) Beard, K. V. \& Pruppacher, H. R., J. Atmos. Sci., 26, 1066-1072 (1969).

(16) Gunn, R., \& G. D. Kinzer, J. Meteor., 6, 243-248 (1949). 